now to be directed largely to research into industrial and commercial capital, and inquiries have already been started into the finance of public companies and the stock of capital assets. Among previous research projects now nearing completion are investigations into trends in retail trading, consumers' expenditure and behaviour during 1920-38, and the location of industry. The inquiry into trends in retail trading traces the changing pattern of retail trading during the past fifty years or so, with particular attention to the development of multiple-shop and co-operative retailing. The project dealing with location of industry was undertaken by the Institute on the invitation of the Board of Trade for the purpose of investigating the private costs of firms which have opened branch manufacturing plants. An interim report was presented to the Board of Trade in 1950 in which the costs of the branches were compared year by year with those of the parent factories. On the basis of the work already done, it is hoped to establish the cost of mobility in certain industries and to assess the relative importance of various location factors in these industries.

\section{Fifth Plant Breeders' Conference}

ThE fifth Plant Breeders' Conference under the auspices of the Agricultural Research Council was held during July 24-26 at the John Innes Horticultural Institution, Bayfordbury. Prof. K. Mather and Dr. E. F. Cheesman represented the Agricultural Research Council. Dr. C. D. Darlington was in the chair. The scope of this year's conference. was widened to include not only members of the British plant breeding institutions but also representatives from the National Vegetable Research Station, Potato Genetics Station, East Malling and Long Ashton Research Stations, the Scottish Horticultural Research Institute, certain university departments and commercial seed firms. This enlargement resulted in a valuable exchange of ideas between research workers in different fields. The morning programmes were devoted to demonstrations of work carried out by the four departments of the John Innes Horticultural Institution. In all, there were thirty different demonstrations. The afternoon programmes consisted of papers followed by discussions. The papers were: "Breeding for Yield", by G. D. H. Bell and R. N. H. Whitehouse; "Variety Testing", by J. C. Haigh ; "Reproduction of Stocks", by F. R. Horne ; "Aids to Plant Breeding", by W. J. C. Lawrence; "Aims and Methods in Plant Breeding", by D. Lewis. A summary of each paper and a full account of the conference will appear in Heredity. The next conference is expected to be held at the Plant Breeding Division, Stormont, Northern Ireland, during July 6-7, 1954.

\section{Brussels Conference on Ultrasonics}

THE proceedings of the International Conference on Ultrasonics, held in Brussels during June 1951 (see Nature, 168, 106; 1951), have now been published in book form by the Koninklijke Vlaamse Academie voor Wetenschappen, Letteren en Schone Kunsten van Belgie (Brussels ; 225 francs), under the auspices of which it took place. Thirty papers, divided into four sections, are covered in about three hundred pages: propagation in fluids ; absorption in electrolytes and vibration potentials; propagation in liquid mixtures and suspensions; propagation in liquid helium. The conference thus dealt with the fundamental aspects of ultrasonics in fluids, in contrast to the international conference in Rome for the previous year, which was concerned mainly with applications in industry and medicine. Many of the papers in the first three sections at the Brussels conference were devoted to the theoretical or practical aspects of ultrasonic absorption considered as viscous or relaxation effects, and some discussion took place on the validity of the supposition that dilatational-as well as shearviscosity plays a part in these phenomena. In the fourth section, there are a number of papers discussing the various theories which have been put forward to explain the existence of 'second sound' in liquid helium $I I$.

\section{Birmingham Symposium on Analytical Chemistry}

Following the International Congress on Analytical Chemistry in Oxford during September 4-9, the Midlands Society for Analytical Chemistry is arranging a symposium on analytical ohemistry, to be held in the Chemistry Department of the University of Birmingham, during September 11-12. The main purpose of the symposium is to give those chemists in the Midlands who are unable to attend the Oxford Congress, the opportunity of hearing papers by, and meeting, analytical chemists of international repute. Prof. Fritz Feigl, of Rio de Janeiro, will be the honorary chairman. The programme on the first day will consist mainly of papers concerned with fundamental concepts of analytical chemistry, and the second day will be devoted to original methods. In addition, visitors will have the opportunity of seeing some of the research projects being carried out in the Research School of Analytical Chemistry at Birmingham, which is one of the largest and best equipped in Europe. The registration fee for non-members of the Society is 10s. and for members 5s. Further details can be obtained from the honorary secretary of the Society, W. T. Edwards, 100 Rymond Road, Birmingham 8.

\section{International Institute of Welding: Meeting in Gothenburg}

THE annual meeting of the International Institute of Welding will be held this year in Gothenburg during September 7-13. On the first day there will be a meeting of the governing Council of the Institute, and the following four days, September 8-11, will be devoted to meetings of the fifteen technical Commissions composed of representatives appointed by the societies belonging to the Institute. On the morning of September 12 visits will be made to shipyards and other works in Gothenburg, and in the afternoon four papers on "Welding in Shipbuilding" will be given by representatives of France, Great Britain, Sweden and the United States. The official programme will close with a further meeting of the governing council on September 13, after which those taking part will be free to join in a series of works visits in Stockholm, Malmö and other industria] centres, organized by the Swedish member societies of the Institute. Further information and enrolment forms can be obtained from Mr. G. Parsloe, SecretaryGeneral, International Institute of Welding, 2 Buckingham Palace Gardens, London, S.W.1.

Museums and Education: Seminar in New York

A SEMINAR on "Museums and Education", organized by the United Nations Educational, Scientific and Cultural Organization, will be held in Brooklyn during September 14-October 12, under the directorship of Dr. Douglas A. Allan, director of the Royel 